\title{
Political Decay and Political Arcadianism
}

\author{
Ronnie Hjorth
}

\begin{abstract}
An account of evil in classical political theory is the concept of evil government. The notion of political decay from good to evil government or to anarchy, the absence of government, among classical political theorists represents both a moral and a political problem. This essay argues that political decay remains a perennial problem because the political condition itself involves the seeds to its own destruction. Moreover, it is claimed that the nostalgic longing to a glorious past for nations or peoples risks turning into what is here labelled 'political arcadianism', fostering futile attempts to return to past conditions. The argument is that political arcadianism when focusing on the imagined past rather than the present is a possible cause of political decay.
\end{abstract}

And in general all men really seek what is good, not what was customary with their forefathers.

Aristotle $^{1}$

Because I cannot hope to turn again,

Consequently I rejoice, having to construct something,

Upon which to rejoice

T.S. Eliot ${ }^{2}$

\section{Introduction}

An account of evil in political theory is the concept of evil government which is often contrasted to that of good government. A famous illustration of this is Ambrogio

1 Aristotle, Politics, edited by H. Rackham (Cambridge Mass.: Harvard University Press, 1932), p. 1269a.

2 T.S. Eliot, Ash-Wednesday, in The Wasteland and Other Poems (New York: Harcourt, 1962 [1930]), p. 58. 
Lorenzetti's frescoes in Palazzo Publico in Sienna painted in 1338-1340. ${ }^{3}$ The fresco entitled Allegory of Good Government illustrates the Thomist view of good government placing the ancient female representation of justice at the centre balancing a pair of scales, and picturing Divine Justice in the image of angels in the pans of the scales dispensing distributive and commutative justice. Central to the painting is the word 'Concordia', written on a speaker's tribune and symbolising the ideal of government in concord, harmony and balance, which is characteristic of the classical natural law doctrine. The contrasting image is that of evil government and satanic power where the pair of scales is broken. Hence, there is a mixing of political and legal doctrine with a theological dogma of good and evil. An equally famous expression is Percy Shelley's poem The Masque of Anarchy (1832) portraying anarchy as the end of government:

\author{
Last came Anarchy: he rode \\ On a white horse, splashed with blood; \\ He was pale even to the lips, \\ Like Death in the Apocalypse.
}

For the classical political theorist the term political decay symbolises a movement from a good system of government to an evil one or to anarchy, the absence of government. Political decay implies moral decay and is clearly regarded a moral evil. For most of modern and contemporary political thought, the categories of good and evil are not essential. Nevertheless, it can be argued, that the preservation of the political condition is regarded by most theorists as morally good, not necessarily because the condition itself is regarded a good, but because it is believed to be instrumental to values conceived to be good, such as justice, equality, wealth or rights.

Fighting political decay involves focusing on ideas and practices that threaten to deteriorate the political condition. There are many possible causes of political decay in contemporary Western societies stemming from things such as political violence, authoritarianism or the introduction of 'post-truth politics' causing political debates less grounded in evidence. ${ }^{4}$ It is not possible to deal with all aspects that are pertinent to understanding the many causes of political decay even if reduced to the Western world. Instead, I have selected one particular aspect that I believe is under-theorised yet a possible threat to the political condition. This is symbolised by the other central term of the paper, 'political arcadianianism'. Arcadianism refers to a backward-looking nostalgic temperament which in political life may result in a reactionary political course. Zygmunt Bauman has recently written about this tendency in contemporary societies. He argues that people have lost faith in utopian thinking turning instead to ideas of the past, hence substituting Utopia with 'Retrotopia'. ${ }^{5}$ Following Bauman, there are possibly similarities

${ }^{3}$ Morris L. Cohen, Law: The Art of Justice (New York: Hugh Lauter Levin, 1992) p. 40.

4On the issue of 'post truth' see Matthew d'Ancona, Post Truth: The New War on Truth and How to Fight Back (London: Ebury Press, 2017).

5 Zygmunt Bauman, Retrotopia (London: Polity Press, 2017). 
between utopianism and arcadianism which should be further explored. Furthermore, the relation between political decay and political arcadianism is not self-evident. In what follows, three questions are central:

1. Is the classical notion of political decay a fruitful assumption when analysing political change?

2. What if any are the parallels between political arcadianism and political utopianism?

3. What if any is the relationship between political arcadianism and political decay?

There are three central arguments of the paper: First, while the distinction between good and evil government is not particularly serviceable, the concept of political decay is not a redundant concept and it is fruitful to assume that the political condition itself involves the seeds to its own destruction and decay. Second, the crisis of political modernity, public distrust in government, and nostalgic longing to an idealised past may result in the perceived past becoming an ideal for the future. Arcadianism, just like utopianism, involves an element of political perfectionism that is not particularly fruitful. However, contrary to utopianism, arcadianism may help restore the lost lifeworld in times of turmoil. Third, while arcadianism is not necessarily problematic it is futile since it is not possible to turn back. Moreover, arcadianism may trigger political decay when turning the attention of the public away from the present to the perceived past downplaying contemporary political challenges and possible solutions. In what follows, political decay is dealt with in the first section while the second section is concerned with political arcadianism.

\section{Political Decay}

The scary vision of the horrid and mutilated remains of what once was a vibrant body politic has inspired political theorists to integrate the dystopic image of political decay into their work. The most well-known example of this is probably the image of the slippery slope found in Plato's Republic showing the degeneration of forms of government from Timocracy to Oligarchy to Democracy and finally to Tyranny. For Plato political decay involves both communities and individual persons. The degradation is moral and political, and it involves both the communities and the persons living in them. ${ }^{6}$ Plato's text opens the door to several interpretations and critical remarks. To some of this I will return briefly, but for the moment it suffices to say that Plato at least underlined that we should not entertain too high a belief in government because states and peoples, like persons, are bound to die. However, the dystopic image also conveys a more optimistic message: that wherever we find ourselves along the slippery slope there is always the opportunity to prevent decay, at least for the time being. Theorising political decay, then, is a way to understand and value the precious and vulnerable nature of the political relationship. Moreover, on the personal level, political decay at least for Plato is the serious consequence

6 Plato, Republic (Cambridge: Cambridge University Press, 2000), book eight and nine. 
of lack of self-control, giving way to temptations such as honour, wealth, excessive freedom or power.

Thomas Hobbes's account of the state of nature as a bellum omnium contra omnes stands out among early modern political theorists conveying another dystopic message, a warning against resisting public order. In comparison to most authors of his times, Hobbes largely rejected the idea that natural law provides a framework for politics within and among nations. Hobbes' theory of the civil condition - the life within the commonwealth - is profoundly different from a situation where the social contract is absent or has failed, because, in his view, the state of nature is brutal and uncivil. ${ }^{7}$ Hobbes clearly viewed political decay as a moral vice and as something that might follow when one acts against one's interest as a citizen, at least when many people fail in this respect. With Hobbes, individual persons are in the foreground, portrayed as lonely and frightened, having to take destiny in their own hands. Michael Oakeshott once reflected on this aspect of Hobbes's Leviathan as the opposite to the myth in Genesis about the Fall of Man portraying mankind as proud and powerful when resisting God, whereas Hobbes 'recalls man to his littleness, his imperfection, his mortality, while at the same time recognizing his importance to himself' ${ }^{8}$ Hobbes viewed the political condition in terms of an established relationship founded on the equality of its members. There is in Hobbes's theory a tradeoff between freedom and order. Ideally, each citizen should 'be contented with so much liberty against other men, as he would allow other man against himself .9 This is the basis for mutual recognition between all citizens of the state, upon which principles of equality and freedom under the laws could be settled. Thus, with Hobbes persons are capable of doing good as well as evil and are capable of rational as well as irrational actions with respect to their conduct as citizens. However, Hobbes also shows that, from time to time, we pursue a conduct driven by pride or lust for power, against our best interest as individual persons, and to the collective body of the state.

While these key texts make central the connection between the moral life and political community, emphasising the moral life of men living together in the pursuit of good government, we learn from the dystopic narratives that political decay unavoidably involves moral decay of both states and citizens. This is so because neither Plato nor Hobbes claimed to have found a cure for political decay, but only ways to limit decay temporarily. Furthermore, even the best practicable state in their view harbours a destructive element. This is made explicit in the final words of The Statesman, where Plato admits that even the best conceivable state would be based on the most striking inequality among human beings, that of slaves and free men. ${ }^{10}$ Stanley Rosen views this passage in the text as an indication by Plato that politics even in the best of forms cannot reach

\footnotetext{
7 See Noel Malcolm, Aspects of Hobbes (Oxford: Clarendon Press, 2002), p. 456 and Annabel Brett, Changes of State: Nature and the Limits of the City in Early Modern Natural Law (Princeton and Oxford: Princeton University Press, 2011) p. 5.

8 Michael Oakeshott, 'Leviathan a Myth' in Hobbes on Civil Association (Indianapolis: Liberty Fund, 2000) p. 163.

9 Thomas Hobbes, Leviathan (Oxford: Clarendon Press, 1909), p. 100 [p. 65] italics in original.

10 This is made explicit in the final words of the Statesman when Plato describes the art of the Statesman as analogous to the art of weaving, uniting both free men and slaves in concord [311b7c6].
} 
perfection, and that perfection in politics therefore is 'trans-political' and remains with philosophy. ${ }^{11}$ Rosen makes a similar observation in is his study of Plato's Republic claiming that,

...the Socratic city does not resolve the problem of unity and difference; rather, it institutionalizes that problem. Socrates's fundamental premise, that the city should be as much like one man as possible, is itself entirely impossible. The tripartite division of powers attributed to the individual soul reveals the discontinuities and factions that are present in each of us by virtue of our very humanity. This becomes obvious when the parts of the soul are restated in political terms. ${ }^{12}$

Rosen's reading of Plato points to the elements of the texts revealing Plato's awareness of the imperfection inherent in every past, present, or future state, and hence, the permanent threat of political decay. For Hobbes the political condition is always vulnerable and depends on the Sovereign's ability to uphold law and order, and of the citizens to support and obey. The main point in Hobbes's Leviathan is the sharp distinction between the brutal state of nature and the state under sovereign rule. The quality of government under a sovereignty may differ. Hence, political decay may take place when the covenant is broken by the contracting parties or when violated by the Sovereign. As is claimed by Gabriella Slomp, 'the political man contains natural man' and always 'carries the state of nature inside his soul' ${ }^{13}$ This is reason enough not to expect the state to be stable and secure. Thus, among two of the most formative political thinkers, the political condition, even when theorised under ideal circumstances, contains the seeds to its own destruction.

Francis Fukuyama has recently dealt with political decay in a slightly different way, taking into account historical change into account. He argues that change for the better sometimes flows from political decay. Political decay is then not regarded a slippery slope from good government to anarchy but as an element of transition from one political order to another:

Political decay is...in many ways a condition of political development: the old has to break down in order to make way for the new. But the transitions can be extremely chaotic and violent; there is no guarantee that political institutions will continuously, peacefully, and adequately adapt to new conditions. ${ }^{14}$

Hence, judging from Fukuyama, political decay is not necessarily dystopic. Clearly, when looking back on the events of political history it is possible to discern how political unrest, war and revolutions have indeed brought about change for the better. However, one has to admit that this is not particularly comforting when confronted with the amount of violence and human suffering that is associated with such processes as they go on. The

11 Stanley Rosen, Plato's Statesman: The Web of Politics (New Haven \& London: Yale University Press, 1995) p. 190.

12 Stanley Rosen, Plato's Republic: A Study (New Haven \& London: Yale University Press, 2005) p. 308.

13 Gabriella Slomp, Thomas Hobbes and the Political Philosophy of Glory (Houndmills, Basingstoke: Palgrave Macmillan, 2000) p. 7.

14 Francis Fukuyama, Political Order and Political Decay (New York: Farrar, Straus, and Giroux, 2014) p. 462. 
principle of violent revolutionary change - 'do evil, that good may come' - is not satisfying but neither is the acceptance of bad government rather than no government. ${ }^{15}$ Fukuyama shows that good government is perhaps not grounded on the same unchanging principles but involves a conception of change that may sometimes be painful.

On a closer look, the distinction between good and evil government addressed in the beginning of this essay is difficult to maintain and perhaps not particularly fruitful either. It is probably better to conceive of the matter more in line with the terminology of G.H. Moore who introduced the terms 'mixed good' and 'mixed evil'. Viewing the political condition as a 'mixed good' means conceiving of it as an intrinsic good that also contains some essential elements that are evil. Alternatively, government is viewed as a 'mixed evil', i.e., as an intrinsic evil that contains as an essential element also something that is good. ${ }^{16}$ The great tradition of political thought has for the most part preferred to view the political condition as a 'mixed good'. Although some authors have been more pessimistic than others; Carl Schmitt and his followers standing out as notable exceptions, not accepting the distinction made by Hobbes, that the political condition is not the state of nature. ${ }^{17}$ Schmitt definitely addressed the problem of political decay to an extent that most contemporary political theorists have not done, but his theory of political decay proceeds from a particular notion of the political condition that most political theorists would not accept. What is clear, however, is that all concepts of political decay originate in a conception of government. Hence, a starting point for dealing with political decay is to consider the vulnerability of the political condition, which is where political decay begins.

The vulnerability of the political condition has been central to several contemporary political theorists reflecting on political decay during the twentieth century. A key author in this respect is Hannah Arendt, who emphasizes the fragile character of the political relationship, and who holds that political associations are close to perfection only in rare moments. Her somewhat romantic of account of the 'treasure' inherent in the revolutionary situation- the 'public happiness' - should not be viewed as indifferent to political decay, but rather the opposite as it acknowledges that 'the treasure was never a reality but a mirage'. ${ }^{18}$ Arendt's work on totalitarianism and the Shoah make her a key thinker of political decay in the modern world: she has identified the many destructive elements of contemporary society and the challenges posed to social science. ${ }^{19}$ Political decay would result in the totalitarian state, which Arendt claimed would involve philosophical reflections in a situation 'in which not even common sense makes sense any

15 Romans 3:8.

16 G.E. Moore, Principia Ethica (Cambridge: Cambridge University Press, 1922), pp. 207-208.

17 Hobbes claimed that sovereignty enables citizens to life a 'retired life' when liberated from the struggle of the pre-political condition. Hobbes, De Cive (Indianapolis, IN and Cambridge: Hacket Publishing, 1993), p. 227. See also Deborah Baumgold, Hobbes's Political Theory (Cambridge: Cambridge University Press, 1988), p. 134. The matter was essential to Leo Strauss in his notes to Schmitt's The Concept of the Political. See Heinrich Meier, Carl Schmitt and Leo Strauss: The Hidden Dialogue (Chicago: The University of Chicago Press, 1995), pp. 98-99.

18 Hannah Arendt, Between Past and Future: Six Exercises in Political Thought (London: Faber \& Faber, 1961) p. 5.

19 Hannah Arendt, The Origin of Totalitarianism (London: André Deutsch, 1986); 'Social Science Techniques and the Study of the Concentration Camps', Jewish Social Studies, 12:1 (1950), pp. 49-64. 
longer'. ${ }^{20}$ Thus, for Arendt political decay, which leads to totalitarianism, marks the beginning of something new and at the same time a going back to the fundamental questions of human life and activity. ${ }^{21}$ Leo Strauss, who shared much of Arendt's experiences as well her intellectual heritage, identified political decay not only with the totalitarian state and its consequences but also with the parallel decline of natural right in political thought and practice. ${ }^{22}$ The notion of natural right according to him sets 'an absolute limit to human arbitrariness' ${ }^{23}$ The reinvigoration of political theory called for by Strauss was partly a reaction to an omission among the social sciences in an age of positivism and historicism, and a call to acknowledge the importance of values and judgement. Therefore, he argues, 'modern utopianism naturally forgets the existence of 'forces of evil' and the fact that these forces cannot be fought successfully by enlightenment'. ${ }^{24}$ Political philosophy for Strauss represented a yardstick for improving political life, which is unavoidably in conflict with the political world..$^{25}$ Thus, both Strauss and Arendt analysed political decay in the modern world in light of the ancient conflict between the philosopher and the state writ large.

Judging from these few examples, the problem of political decay is far from straightforward, but nevertheless points to what seems to be a perennial problem for the political condition, and a problem to be experienced anew by every generation. We learn that the vulnerability of the political condition probably is unavoidable and a necessary element of the political condition itself. Having accepted that, the main worry should be to identify and confront whatever it is that threatens the political condition in the time and the place we live.

\section{Political Arcadianism}

A well-known enemy of the political condition is the temptation to avoid dealing with the world we live in while engaging instead in utopian dreams about brighter worlds. The utopian temperament involves a belief in political perfection, which conservative political thinkers have sought to resist by adopting a sceptical posture towards what they have identified as Jacobinism, or a Baconian spirit of political engineering. ${ }^{26}$ Utopianism is associated with the progressive ideologies of the modern age and is an expression of modernity in politics and society. While utopianism may still hold sway in the Western world, we are sometimes urged to rethink the modern political ideals and to reject the

${ }^{20}$ Hannah Arendt, 'Philosophy and Politics', Social Research, 57: 1 (1990[1954]), p. 102.

21 Ibid.,p. 99-103.

22 Leo Strauss, Natural Right and History (Chicago: The University of Chicago Press, 1953).

${ }^{23}$ Leo Strauss, 'What Can We Learn from Political Theory?', The Review of Politics, 69: 4 (2007 [1942]), p. 521.

24 Ibid., p. 524.

25 See Michael P. Zuckert \& Catherine H. Zuckert, Leo Strauss and the Problem of Political Philosophy (Chicago: The University of Chicago Press, 2014) and Richard L. Velkley, Heidegger, Strauss, and the Premises of Philosophy: On Original Forgetting (Chicago: The University of Chicago Press, 2015), Ch. 6.

26 Edmund Burke, Reflections on the Revolution in France (London: The Walter Scott Publishing Company); Michael Oakeshott, The Politics of Faith and the Politics of Scepticism (New Haven \& London: Yale University Press, 1996). 
political project of modernity. Such is the case with nostalgic nationalism and protectionism, aiming to make this or that nation great again when referring to a more prosperous past. In these trends looms a temptation that is harder to resist, especially for conservatives. This is the inclination not to look forward into future brighter worlds, but instead to turn around and view as an ideal a shimmering past. This I have labelled political arcadianism.

The term arcadianism refers to an idyllic narrative about the rural life expressed in culture, life-style and literally fiction. The term is represented in the political literature, for example in the early modern period, as a reaction to naturalism, and later in the ecological movement and in the context of Post-colonialism in reaction to liberalism. ${ }^{27}$ Arcadian ideals in contemporary political life can supposedly be very different, ranging from material things such as restoring a branch of industry that has lost its place in global competition to non-material values, such as enforcing traditional religious and social norms, or the preservation of traditional gender roles. While not central to the political literature, or dealt with systematically, there seems to be a genealogy of the concept perhaps worthy of further exploration. However, space does not permit this theme to be further elaborated here.

More precisely, political arcadianism is understood here as the attempt, by political means, to restore an imagined past, or to model political reform on the basis of a perceived past. It is important to distinguish between political arcadianism in this precise sense and an arcadian temperament which may be quite harmless, for example when looking back on a happy and innocent childhood, or on a time past that for some reason embodies what one feels to be the perfect condition of life. Such a longing is associated with a sense of nostalgia or sentimentality that is often non-political. But even when it is expressed in political life arcadianism can be harmless. However, arcadianism may sometimes take the form of a reaction, attempting by political means to return to a condition of a glorified past thereby presenting a seemingly easy way out of contemporary political challenges. The important thing is that the past, however conceived of, functions as a model for reshaping, by means of political power, what has been lost. When looking backwards for guidance, there is the tendency to refrain from recalling the elements of the past condition that was not good. Political arcadianism is thus likely to invent its own history when idealising the past and is likely to ignore informed historical criticism or uncomfortable facts about the state of affairs in the past.

It is difficult to discern what consequences political arcadianism may have for political life. For example, it is hard to see how nostalgic and pastoral ideals could foster a modern totalitarian state. Yet, this was the case with the fascist political ideology that eventually led to totalitarianism in the 1930s, such as in Nazi Germany. It is possible that arcadianism belongs to the modern world as a critical perspective to it and that it may even borrow elements of modernity. Political arcadianism in the modern context may take the nation state as its appropriate domain and its advocates would make use of modern

27 J.H. Burns \& Mark Goldie, The Cambridge History of Political Thought 1450-1700 (Cambridge: Cambridge University Press), p. 342; Andrew Dobson, Green Political Thought $3^{\text {rd }}$ Edition (London \& New York: Harper Collins, 2000), p. 31; Pavan Kumar Malreddy et al (Eds.), Reworking Postcolonialism: Globalization, Labour and Rights (Houndmills Basingstoke: Palgrave Macmillan, 2015), p. 24. 
communication technologies and media. Political arcadianism can possibly support antimodern (or even post-modern) political projects, supporting a future-oriented political order but referring to ideals of the past. While political modernity has always involved utopianism, postmodernism, just like anti-modernism, may have contributed to the kind of particularistic and relativist thinking by providing intellectual support to various reactions towards political modernity. These reactions may invite political arcadianism.

While the term arcadianism has not been much elaborated in the political literature, at least not in any systematic sense, it is important to the wartime poetry of W.H. Auden and is implicit in much of T.S. Eliot's work during the same period. To Auden, arcadianism symbolises a particular arcadian temperament, looking back on an innocent past. The theological aspect of this, which is central to the works of both Auden and Eliot, is the human inclination to look back on the perfect condition of humanity before the fall, expressing a futile desire to re-enter the Garden of Eden. Alan Jacobs explains the position accordingly quoting Auden:

Humanity must turn its back on that original Garden and look for the experience of wholeness elsewhere; 'but you will not find it /Until you have looked for it everywhere and found nowhere that is not a desert.' Arcadianism is, in brief, the refusal of this hard and purgative path, and the corresponding longing for the angels and their swords simply to go away. Hoping to return to the Garden is like hoping to return to the womb. ${ }^{28}$

Thus, arcadianism has to do with longing for wholeness, presenting a seemingly simple way to overcome problems and imperfection. Arcadianism also involves a contrasting image, just like Lorenzetti's frescoes described in the introduction. In the case of Auden and Eliot, such a contrasting image is the 'the purgatory path' of human existence in a dry landscape, 'for the time being' wandering between the Arcade and the second coming of Christ. The point they make is that there is no turning back. There is simply no choice but to resign the futile hope to restore what forever is lost and what humans cannot re-create.

In another context arcadianism represents not only a nostalgic longing but also a search for identity in an alienating world. Critical Theory pictures the dilemma between political modernity and the arcadian temperament. Critical theorists have generally been pessimistic about human rationality and have sought to combine an urge to develop political and cultural modernity while cultivating an awareness of the dangers attached to modernity. ${ }^{29}$ Critical Theory rejects nostalgia and the attempts to copy models of the past to contemporary politics and culture. A central element in this literature is the contradictions of modern society between the impersonal forces of economic and political systems, and the lifeworld where people relate to themselves and to others. ${ }^{30}$ One particular work that stands out in this respect is Walter Benjamin's complex and unfinished

28 W. H. Auden, For the Time Being: A Christmas Oratory, edited by Alan Jacobs (Princeton \& Oxford: Princeton University Press, 2013), p. xxii.

29 See for example Theodor W. Adorno, and Max Horkheimer, Dialectic of Enlightenment (New York: Verso, 1999).

30 Jürgen Habermas, The Theory of Communicative Action, Volume Two. Lifeworld and System: A Critique of Functionalist Reason (Boston: Beacon Press, 1987). 
sketches published as The Arcades Project. ${ }^{31}$ Perhaps the notion of arcadianism is one lens through which to read this strange collection of papers with its contrasting images of the modern city, described by Benjamin in terms of the Paris arcades, made of iron and glass, and the alienated people picking up pieces of the past when struggling to re-create a lost lifeworld. They are what Benjamin characterises 'collectors'. The collector 'takes up the struggle against dispersion' against the scattered images and representations of the world. 32 For Benjamin this is also an image of the intellectual, of the historian. In his view, history unfolds as we experience it. The history of the nineteenth century he pictures as dreams about the past:

The new, dialectical method of doing history presents itself as the art of experiencing the present as waking world, a world to which that dream we name the past refers in truth. To pass through and carry out what has been in remembering the dream! Therefore: remembering and awakening are most intimately related. Awakening is namely the dialectical, Copernican turn of rememberance. // The nineteenth century, a spacetime $<$ Zeitraum $>$ (a dreamtime $<$ Zeit-traum $>$ ) in which the individual consciousness more and more secures itself in reflecting, while the collective consciousness sinks into ever deeper sleep. [...] We must follow in its wake so as to expound the nineteenth century - in fashion and advertising, in buildings and politics - as the outcome of its dream visions. ${ }^{33}$

There is a curious connection between these formulations by Benjamin and the political writings of Arendt. For Arendt, political theory is conceived as 'being-in-the world', wandering and reflecting on the human condition of the twentieth century. To Arendt, the absence of tradition in the modern world makes possible a renewal of the political condition in a 'non-time-space'. ${ }^{34}$ Prejudice, she argues, emerges out of the past while in the modern world, we can make decisions under conditions where familiar standards no longer make sense. The political condition, ultimately 'an in-between space' where people interact, is in her view not dependent on exogenous standards:

The loss of standards, which does indeed define the modern world in its facticity and cannot be reversed by any sort of return to the good old days or by some arbitrary promulgation of new standards and values, is therefore a catastrophe in the moral world only if one assumes that people are actually incapable of judging things per se, that their faculty of judgement is inadequate for making original judgements, and that the most we can demand of it is the correct application of familiar rules derived from already established standards. 35

31 The English title of Benjamin's work is The Arcades Project while the German original title is Das Passagen-Werk, in both cases referring to a Paris context. The term arcadianism is to my knowledge not used by Benjamin and the choice of English title is probably a coincidence.

32 Walter Benjamin, The Arcades Project, translated by Howard Eiland and Kevin McLaughlin (Cambridge Mass. \& London: The Belknap Press of Harvard University Press, 1999), p. 211.

33 Ibid., p. 389.

34 Arendt, Between Past and Future, p. 13.

35 Hannah Arendt, 'Introduction Into Politics', The Promise of Politics, edited by Jerome Kohn (New York: Schocken Books, 2005), p. 104. 
The promise of politics in Arendt's view, is the promise of freedom only to appear in 'the unique intermediary space of politics' ${ }^{36}$ To achieve this is not to escape history but to realise that history does not necessarily determine our judgements and actions in political matters. In other words, the attempt to collect and to construct something upon which to rejoice may well involve arcadian ideals, but is not necessarily related to political action, and hence not to political arcadianism. Perhaps it is fruitful to conceive of the arcadian temperament as a natural inclination among humans to look backwards in search of a perspective, an orientation or a means to acquire meaning, such as we do when relating to a tradition of thought. When experienced in social and cultural life, the arcadian temperament has to do with identity, belonging and a lifeworld, that helps people to cope in a changing world, to search for an understanding and a perspective, or to withstand suffering and to uphold human dignity and respect in hard times.

Political arcadianism, by contrast, I take to be a nostalgic reactionary political programme sustained by power, even democratic power, seeking to restore a perceived paradise lost. In that sense political arcadianism is actually forward-aiming but backwardlooking, and in a sense a cousin of utopianism. Political arcadianism is perhaps more about an imagined and wished for future than an adequate account of the past. It looks to the imagined past for guidance rather than relying on grand schemes or abstract principles. For this reason political arcadianism is easier to relate to than utopianism since it does not consist of abstract theories or an esoteric discourse. Political arcadianism relies on wellknown and accessible narratives creating a political myth. The most serious consequence of political arcadianism is that it risks turning the attention of the public away from the political problems of the day, obscuring the responsibility of all members of a political community to uphold and maintain the political condition. That is why political arcadianism may cause political decay.

It is possible that both utopianism and arcadianism always have a place in political reflection and action by representing different temperaments, one that is forward-looking and one that is backward-looking. If that is so, the important point to underline is that neither temperament should lead us to neglect dealing with the present for the longing for a golden future or the good old days. The past is always a part of the present and informs our actions as much as utopian dreams of the future may do. Eliot famously writes in Burnt Norton:

Time past and time future

What might have been and what has been

Point to one end, which is always present. ${ }^{37}$

Rejecting political arcadianism is not the same as rejecting the past. The words of Eliot in this context convey the insight that the past as well as the future is important, and perhaps impossible to neglect, but that it all points to the present.

36 Ibid., p. 95.

37 T.S. Eliot, Four Quartets (New York: Harcourt, 1971 [1943]), p. 14. 


\section{Conclusions}

To conclude, the main arguments of this paper are the following: First, that the political condition involves the seeds to its own destruction through political decay, and that this is not any different today from what many previous generations have experienced. Second, that political arcadianism risks fostering futile attempts to return to what can never more be (and what perhaps never was). By turning the attention of the public away from the present to the past, political arcadianism may threaten the political condition and cause political decay. However, resisting political arcadianism is not a sufficient means to avoid political decay. Viewing the political condition as a solution to the human predicament may not suffice. Perhaps, that is why Hobbes regarded the State of Nature as immanent in all of human life, and the ability to contain the evil of human relations through political institutions an option only for the time being, but never ever to restore among humans on Earth the peace and tranquillity enjoyed in the Arcade.

Ronnie Hjorth, Swedish Defence University ronnie.hjorth@fhs.se

\section{Bibliography}

Adorno, Theodor W. \& Horkheimer, Max. Dialectic of Enlightenment. New York: Verso, 1999.

Arendt, Hannah. 'Social Science Techniques and the Study of the Concentration Camps'. Jewish Social Studies 12:1 (1950), pp. 49-64.

Arendt, Hannah. Between the Past and Future: Six Exercises in Political Thought. London: Faber \& Faber, 1961.

Arendt, Hannah. The Origin of Totalitarianism. London: André Deutsch, 1986.

Arendt, Hannah. 'Philosophy and Politics'. Social Research 57:1 (1990), pp. 73-103.

Arendt, Hannah. 'Introduction Into Politics', in The Promise of Politics, edited by Jerome Kohn. New York: Schocken Books, 2005).

Auden, W. H. For the Time Being: A Christmas Oratory, edited by Alan Jacobs. Princeton \& Oxford: Princeton University Press, 2013.

Aristotle. Politics, edited by H. Rackham. Cambridge Mass.: Harvard University Press, 1932.

Bauman, Zygmunt. Retrotopia. London: Polity Press, 2017.

Baumgold, Deborah. Hobbes's Political Theory. Cambridge: Cambridge University Press, 1988.

Benjamin, Walter. The Arcades Project, translated by Howard Eiland and Kevin McLaughlin. Cambridge Mass. \& London: The Belknap Press of Harvard University Press, 1999.

Brett, Annabel. Changes of State: Nature and the Limits of the City in Early Modern Natural Law. Princeton \& Oxford: Princeton University Press, 2011.

Burke, Edmund. Reflections on the Revolution in France. London: The Walter Scott Publishing Company. 
De Ethica. A Journal of Philosophical, Theological and Applied Ethics Vol. 5:1 (2018)

Burns, J.H. \& Goldie, M. (eds). The Cambridge History of Political Thought 1450-1700. Cambridge: Cambridge University Press, 1991.

Cohen, Morris. Law: The Art of Justice. New York: Hugh Lauter Levin, 1992.

D'Ancona, Matthew. Post Truth: The New War on Truth and How to Fight Back. London: Ebury Press, 2017.

Dobson, Andrew. Green Political Thought, $3^{\text {rd }}$ Edition. London \& New York: Harper Collins, 2000.

Eliot, T.S. Four Quartets. New York: Harcourt, 1971.

Eliot, T.S. The Wasteland and Other Poems. New York: Harcourt, 1962.

Fukuyama, Francis. Political Order and Political Decay. New York: Farrar, Straus, and Giroux, 2014.

Habermas, Jürgen. The Theory of Communicative Action, Volume Two. Lifeworld and System: A Critique of Functionalist Reason. Boston: Beacon Press, 1987.

Hobbes, Thomas. Leviathan. Oxford: Clarendon Press, 1909.

Hobbes, Thomas, De Cive. Indianapolis, IN \& Cambridge: Hackett Publishing, 1993.

Holy Bible. King James Version. Cambridge: Cambridge University Press.

Lane, Melissa. Method and Politics in Plato's Statesman. Cambridge: Cambridge University Press, 1998.

Malcolm, Noel. Aspects of Hobbes. Oxford: Clarendon Press, 2002.

Malreddy, Kumar Pavan et al (eds). Reworking Postcolonialism: Globalization, Labour and Rights. Houndmills Basingstoke: Palgrave Macmillan, 2015.

Meier, Heinrich. Carl Schmitt and Leo Strauss: The Hidden Dialogue. Chicago: The University of Chicago Press, 1995.

Moore, G.E. Principia Ethica. Cambridge: Cambridge University Press, 1922.

Oakeshott, Michael. The Politics of Faith and the Politics of Scepticism. New Haven \& London: Yale University Press, 1996.

Oakeshott, Michael. Hobbes on Civil Association. Indianapolis: Liberty Fund, 2000.

Plato, Republic. Cambridge: Cambridge University Press, 2000.

Plato, Statesman. Cambridge: Cambridge University Press, 1995.

Rosen, Stanley. Plato's Statesman: The Web of Politics. New York: Yale University Press, 1995.

Rosen, Stanley. Plato's Republic: A Study. New Haven \& London: Yale University Press, 2005.

Schmitt, Carl. The Concept of the Political. Chicago: The University of Chicago Press, 1986.

Slomp, Gabriella. Thomas Hobbes and the Political Philosophy of Glory. Houndmills Basingstoke: Palgrave Macmillan, 2000.

Strauss, Leo. Natural Right and History. Chicago: The University of Chicago Press, 1953.

Strauss, Leo. 'What Can We Learn from Political Theory?'. The Review of Politics, 69:4 (2007 [1942]).

Velkley, Richard L. Heidegger, Strauss, and the Premises of Philosophy: On Original Forgetting Chicago: The University of Chicago Press, 2015.

Zuckert, Michael P. \& Zuckert, Cathrine H. Leo Strauss and the Problem of Political Philosophy. Chicago: The University of Chicago Press, 2014. 
De Ethica. A Journal of Philosophical, Theological and Applied Ethics Vol. 5:1 (2018) 